\title{
Development of a strategy for the development of small business in the confectionery sector and assessment of the effectiveness of it
}

\author{
Yulia Verchenko ${ }^{1, *}$, Irina Bogdanova ${ }^{1}$, Elena Kostoglodova ${ }^{2}$, and Yana Kurinova ${ }^{2}$ \\ ${ }^{1}$ Don State Technical University, Gagarin Square, 1, 344003 Rostov-on-Don, Russia \\ ${ }^{2}$ Rostov State Economic University, B. Sadovaya str., 69, 344002 Rostov-on-Don, Russia
}

\begin{abstract}
The article highlights the issues related to the analysis of the activities of small business confectionery companies and the justification of the need to adjust the implemented development strategy in modern economic conditions. The analysis of the activities of three small businesses in the confectionery industry is carried out. The directions of strategies for the development of small business enterprises in the confectionery industry have been determined, a systematic approach to assessing strategic development has been formed and tested on the example of one of the enterprises in terms of commodity turnover and commercial transaction and cost intensity and profitability. The conclusion is made about the possibility of the system of indicators of the effectiveness of the strategy to correctly assess the state, measure its quality level, identify significant shortcomings in the organization of management and used reserves and outline ways of improvement.
\end{abstract}

\section{Introduction}

To ensure the effective functioning of small business confectionery enterprises in the modern environment, it is necess ary to assess the strategy for the development of activities, including studying and assessing such indicators as turnover, profitability and cost intensity of business, the effectiveness of transactions [1-4].

The study of the works of modern researchers [5-8] is justified by the purpose of developing an approach to the formation of a strategy for the development of confectionery enterprises of small business and identifying a more acceptable methodology for assessing its effectiveness. In the course of the study, an analysis of the activities of three enterprises of the confectionery industry of the Rostov region was carried out, the need to revise their strategic development in terms of such indicators as monthly production and sales of products for the period 2018 - 2020 was substantiated [9-12].

The results of the study made it possible to form the directions of strategies for the development of small confectionery enterprises and propose a system of indicators to justify the development of a strategy for the development of confectionery enterprises [13-16].

* Corresponding author: u_verchenko@mail.ru 
Proposals for improving the strategy and assessing its effectiveness are presented as a justification base.

The aim of the study is to study the activities and develop an approach to formulating a business development strategy and assessing the effectiveness of confectionery enterprises in the small business of the Rostov region, as well as practical testing of the proposed solutions.

\section{Materials and methods}

Russia, like any state, has different levels of socio-economic development of its regions [3]. The object of our research is small confectionery enterprises of the Rostov region. The intensity of the development of small business in the region equally depends on certain conditions, such as objective economic factors (capacity of the regional market, transport and geographical position of the territory, the degree of infrastructure development, etc.) and on the personal activity of the subjects [4]. For a more complete study of the activities of small enterprises in the Rostov region, we have collected data and conducted an analysis of the activities of small confectionery enterprises in Rostov-on-Don. Production and sales of fin ished products by enterprises over the past three years are presented in Table 1.

Table 1. Production and sales of confectionery products by confectionery enterprises for 2018-2020

\begin{tabular}{|l|c|c|c|}
\hline \multicolumn{1}{|c|}{ Indicators / Years } & 2018 & 2019 & 2020 \\
\hline $\begin{array}{l}\text { Production and sales of products (tons), by } \\
\text { an enterprise 1 }\end{array}$ & 44.1 & 68.3 & 61.4 \\
\hline $\begin{array}{l}\text { Dynamics compared to the previous year } \\
\text { in\% }\end{array}$ & 100 & 154.9 & 89.9 \\
\hline $\begin{array}{l}\text { Production and sales of products (tons), by } \\
\text { an enterprise 2 }\end{array}$ & 77.8 & 109.3 & 112.4 \\
\hline $\begin{array}{l}\text { Dynamics compared to the previous year } \\
\text { in\%. }\end{array}$ & 100 & 140.5 & 102.4 \\
\hline $\begin{array}{l}\text { Production and sales of products (tons), by } \\
\text { an enterprise 3 }\end{array}$ & 119.3 & 121.8 & 103.6 \\
\hline $\begin{array}{l}\text { Dynamics compared to the previous year } \\
\text { in\%. }\end{array}$ & 100 & 102.1 & 85.1 \\
\hline
\end{tabular}

Consider the production and sale of confectionery products by enterprises in 2020 by months (Figure 1). 


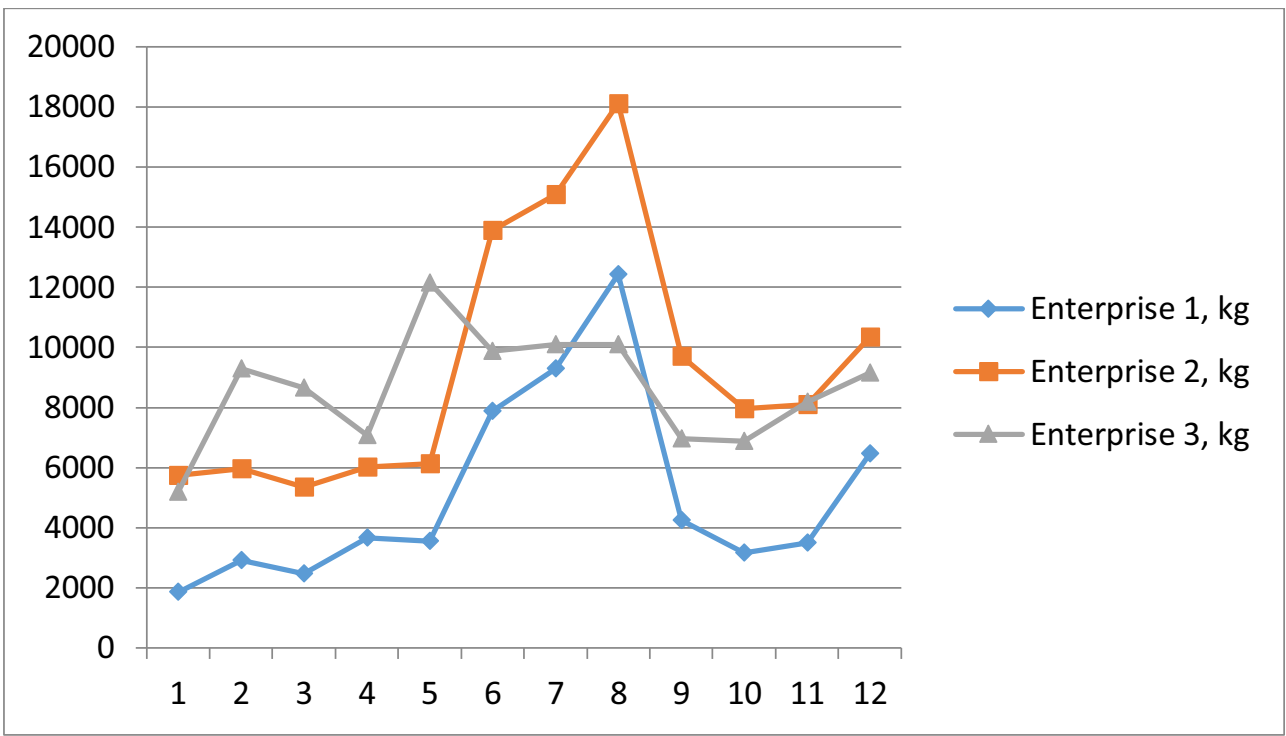

Fig.1. Production and sale of confectionery products by enterprises in 2020 by months, in $\mathrm{kg}$

The study shows that the production and sale of confectionery products at enterprises 1 and 2 in the summer period is higher than at other times of the year, with the exception of November and December, since in these months production and sales are higher due to the New Year holidays. [6] For example, an increase in the production of confectionery products in May at enterprise 3 is due to the fact that it produces sugary confectionery products, the shelf life of which is longer than that of flour products, as in enterprises 1 and 2.

In the course of our research, it was revealed that for the analyzed enterprises it is necessary to justify the development strategy and modernize management. [7] Little attention is paid to marketing methods, in particular, pricing policy, there is no de finite good and clear development strategy, goals are not defined and the main tasks are not formed. And also, at these enterprises, there is practically no analysis of the economic activities of enterprises, which could subsequently determine the effectiveness of all its activities, little attention is paid to planning, etc.

\section{Results}

The development strategy of the confectionery industry at the present stage of economic development forms fundamentally new tasks for solving in the new millennium. Currently, the unstable quality of raw materials with a wide range of safety indicators is a significant inhibiting factor in organizing the production of confectionery products from the standpoint of healthy nutrition [8].

The main directions of development strategies for small confectionery enterprises are shown in Table 2 .

Table 2. Directions of strategies for the development of small confectionery enterprises

\begin{tabular}{|l|c|}
\hline \multicolumn{2}{|c|}{ Directions of development strategies for small confectionery enterprises of the Rostov region } \\
\hline Management modernization & Production modernization \\
\hline Concentration and integration & $\begin{array}{r}\text { The use of waste-free, ecologically highly } \\
\text { efficient equipment of a new generation }\end{array}$ \\
\hline
\end{tabular}




\begin{tabular}{|l|r|}
\hline Governmental support & Application of modern types of packaging \\
\hline Getting a franchise from large companies & Using high quality raw materials \\
\hline Using network marketing techniques & Portfolio expansion \\
\hline Market monitoring and market preferences & Increasing the competitiveness of products \\
\hline Perfection & $\begin{array}{r}\text { Increasing the investment attractiveness of } \\
\text { the organization }\end{array}$ \\
\hline Controlling & Following the principles of a healthy lifestyle \\
\hline Justification of development strategies & Production automation \\
\hline $\begin{array}{l}\text { Creation of associations (unions) to perform } \\
\text { the functions of commodity circulation and } \\
\text { study the market environment }\end{array}$ & \\
\hline
\end{tabular}

In our analysis, it was revealed that the products of many small confectionery enterprises are low competitive and, in this regard, protection and support of domestic producers and the country's domestic market at the state level is necessary. [9] It is required to take such measures as: allocation of targeted loans to enterprises; reduce taxation; abolish the duty on technological equipment for the confectionery industry, which is currently not manufactured in Russia. [10] To protect domestic producers, it is necessary to reduce imports of finished confectionery products by increasing customs duties. In order to reduce the cost of manufactured confectionery products, on the contrary, it is necessary to reduce duties on them or even abolish them for raw materials that are not produced in Russia [11]. This requires the use of marketing tools in management. In particular, such marketing tools as developing a pricing policy, occupying a niche in the market, applying methods of network marketing, conquering new sales markets for products, conducting a deep analysis of economic activities and planning their further development.

\section{Discussion of the results}

The indicators of the justification for the development of development strategies, in our opinion, should be subdivided into indicators of the efficiency of the enterprise with suppliers and buyers, which will allow us to assess the efficiency of operations for the purchase of the necessary raw materials and materials for the production of products and their sale. [12] In addition, the indicators recommended below for assessing the effectiveness of work with suppliers and consumers of products can be calculated both for the confectionery enterprise as a whole for a certain period (for a year), and for individual suppliers (Table 3).

Table 3. Directions of strategies for the development of small confectionery enterprises [13]

\begin{tabular}{|l|l|l|}
\hline \multicolumn{2}{|c|}{$\begin{array}{c}\text { The system of indicators to justify the development of a strategy for the development } \\
\text { of confectionery enterprises }\end{array}$} \\
\hline $\begin{array}{c}\text { Performance indicators of } \\
\text { small confectionery } \\
\text { enterprises with suppliers }\end{array}$ & \multicolumn{2}{|c|}{$\begin{array}{c}\text { Performance indicators of small confectionery enterprises } \\
\text { with consumers }\end{array}$} \\
\hline $\begin{array}{c}\text { Coverage of commercial } \\
\text { proposals }\end{array}$ & $\begin{array}{l}\text { Indicators characterizing } \\
\text { the promotion process }\end{array}$ & $\begin{array}{c}\text { Indicators characterizing } \\
\text { financial flows }\end{array}$ \\
\hline $\begin{array}{l}\text { - coefficient of fulfillment } \\
\text { of contractual obligations }\end{array}$ & $\begin{array}{l}\text { - link ratio of goods } \\
\text { movement }\end{array}$ & - material turnover ratio \\
\hline $\begin{array}{l}\text { - share of supplies of raw } \\
\text { materials in the total amount } \\
\text { of supplies }\end{array}$ & $\begin{array}{l}\text { - the share of commodity } \\
\text { stocks }\end{array}$ & $\begin{array}{l}\text { - accounts receivable } \\
\text { turnover ratio }\end{array}$ \\
\hline $\begin{array}{l}\text { - the degree of development } \\
\text { of direct economic ties }\end{array}$ & & - the amount of net profit \\
\hline
\end{tabular}




\begin{tabular}{|l|l|l|}
\hline $\begin{array}{l}\text { - the share of supplies of } \\
\text { raw materials and materials } \\
\text { of high quality }\end{array}$ & & \\
\hline
\end{tabular}

The proposed system of indicators for substantiating the development of a development strategy makes it possible to correctly assess the state, measure its quality level, identify existing shortcomings in the organization of management and unused reserves, and outline ways of improvement [14].

As an evidence base, we will make a calculation for a confectionery enterprise using the initial data presented in table 4,5 .

Table 4. Confectionery data for 2019 - 2020

\begin{tabular}{|l|c|c|c|}
\hline \multicolumn{1}{|c|}{ Indicators / Years } & 2019 & 2020 & 2021 (forecast) \\
\hline Common data & 1596000 & 1642000 & 2010200 \\
\hline 1. Profit, rub. & 7980000 & 8210000 & 10356900 \\
\hline 2. Trade turnover, rub. & 1318320 & 1319650 & 1325690 \\
\hline $\begin{array}{l}\text { 3. Source of own funds on the balance } \\
\text { sheet, rubles }\end{array}$ & - & 1461170 & 3884425 \\
\hline $\begin{array}{l}\text { 4. Average value of long-term loans and } \\
\text { borrowings, rubles. }\end{array}$ & - & - & 68230 \\
\hline $\begin{array}{l}\text { 5. Investments on the position "Souffle", } \\
\text { rubles. }\end{array}$ & - & - & 18763 \\
\hline $\begin{array}{l}\text { 6. The expected amount of profit on the } \\
\text { position "Souffle", rubles. }\end{array}$ &
\end{tabular}

Table 5. Data of the confectionery enterprise "Sladost Dona" in 2020

\begin{tabular}{|l|c|c|}
\hline \multicolumn{1}{|c|}{ Data on commercial transactions } & $\begin{array}{c}\text { 1st transaction } \\
\text { (supplier 1) }\end{array}$ & $\begin{array}{c}\text { 2nd } \\
\text { transaction } \\
\text { (supplier 2) }\end{array}$ \\
\hline 1. Profit, rub. & - & 2400 \\
\hline 2. Trade turnover, rub. & - & 12000 \\
\hline $\begin{array}{l}\text { 3. The expected amount of profit from a commercial } \\
\text { transaction, thousand rubles. }\end{array}$ & 21300 & 19250 \\
\hline $\begin{array}{l}\text { 4. Investments in the purchase of raw materials and } \\
\text { materials from suppliers and production costs, thousand } \\
\text { rubles. }\end{array}$ & 83200 & 79900 \\
\hline
\end{tabular}

So,the indicator of profitability of sales is a criterion, and shows how much profit falls on a unit of products sold. [15] Let's calculate it with the following formulas: (formula 1):

$$
k 1=\frac{P}{\mathrm{~V}}
$$

Where $k 1$ - the coefficient of profitability of sales;

$\mathrm{P}$ - the annual amount of profit according to the balance sheet of the enterprise,

thousand rubles;

$\mathrm{V}-$ annual turnover, thousand rubles.

$$
k 1(2019)=\frac{1596000}{7980000}=0,2
$$




$$
\begin{gathered}
k 1(2020)=\frac{1642000}{8210000}=0,2 \\
k 1\left(\text { forecast 2021) }=\frac{2010200}{10356900}=0,19\right.
\end{gathered}
$$

The calculations show that there are practically no changes per unit of products sold, but there is a slight downward trend.

An increase in $k 1$ is a consequence of an increase in prices for goods sold or a decrease in the cost of promoting goods to consumers at constant prices. The calculation can be made for each commercial transaction in the sale of products. You can calculate the return on sales ratio for each commercial transaction for the sale of confectionery (2):

$$
k i j=\frac{P i . j}{\mathrm{Vi} . j}
$$

Where ki.j - the profitability ratio of the i-th commercial transaction of the $\mathrm{j}$-th trading operation;

$\mathrm{P} \mathrm{i.j} \mathrm{-} \mathrm{the} \mathrm{amount} \mathrm{of} \mathrm{profit} \mathrm{of} \mathrm{the} \mathrm{i-th} \mathrm{commercial} \mathrm{transaction} \mathrm{of} \mathrm{the} \mathrm{j-th} \mathrm{trading} \mathrm{operation,}$ thousand rubles;

In $\mathrm{i} . \mathrm{j}$ - the turnover of the $\mathrm{i}$-th commercial transaction of the $\mathrm{j}$-th trading operation, thous and rubles.

$$
k 1.1(2020)=\frac{2400}{12000}=0,2
$$

Knowing the costs stipulated by contracts for organizing the delivery (bringing) goods from suppliers to consumers, as well as for organizing the conclusion of contracts, you can calculate the profit from this transaction by deducting costs from income. However, even not the main groups of expenses, it is possible to determine the return on equity for a number of prospective suppliers and the feasibility of concluding an agreement with one or another supplier and draw a conclusion about the effectiveness of a commercial transaction (3):

$$
R_{k}^{i}=\frac{P^{i}}{\mathrm{~K}^{i}} \times 100 \%
$$

Where $R_{k}^{i}$ - return on equity from a commercial transaction, $\%$;

$P^{i}$ - the expected amount of profit from the $\mathrm{i}-$ th commercial transaction, thous and rubles;

$K^{i}$ - investment in the i-th purchase of raw materials and materials from suppliers and production costs, thousand rubles.

Possible first supplier:

$$
R_{k}^{1}=\frac{21300}{83200} \times 100 \%=26 \%
$$

Possible second supplier:

$$
R_{k}^{2}=\frac{19250}{79900} \times 100 \%=24 \%
$$

According to the calculation, it should be noted that it is advisable to make a deal with the first supplier.

To reflect the relationship between the profitability of turnover and the number of inventory turnovers at a given level of profitability, one can use the profitability of inventories (4), which reflects the relationship between the profitability of turnover and the number of inventories at a given level of profitability: 


$$
R_{\mathrm{z}}=\frac{P}{\mathrm{z}} \times 100 \%
$$

Where $R_{z}$ - profitability of inventory, $\%$;

$\mathrm{P}$ - the annual amount of profit for the commodity item, thousand rubles;

$\mathrm{Z}$ - the sum of average commodity stocks for a commodity item at the purchase price, thous and rubles.

$$
R_{z}=\frac{18763}{68230} \times 100 \%=28 \%
$$

The efficiency of the enterprise as a whole depends on the effectiveness of measures to organize economic relations with suppliers, such as identifying sources of procurement, searching for suppliers and purchasing the necessary raw materials and materials, as well as concluding agreements with them on mutually beneficial terms. According to calculations, we observe the average efficiency of interaction [16]

The effectiveness of economic relations with consumers of products is determined by the level of satisfaction of the population's demand for goods in specific conditions with an economically necessary minimum of associated costs: labor, material, financial resources, the speed of goods turnover, an increase in labor productivity, and an increase in profitability.

In the first group, as a generalizing one, it is proposed to use the indicator of the level of coverage of commercial proposals (profitability of permanent capital) of a confectionery enterprise with suppliers of raw materials and materials on concluding an agreement with them for the supply of goods, calculated as a percentage (5).

$$
R=\frac{P}{\mathrm{~K}+\mathrm{K} Z_{a v}} \times 100 \%
$$

Where $R$ - the return on permanent capital, \%;

$\mathrm{P}$ - the annual amount of profit for the commodity item, thousand rubles;

$\mathrm{K}$ - the source of equity on the balance sheet, thousand rubles;

$\mathrm{KZav}$ - the average value of long-term loans and borrowings for the period, thousand rubles.

$$
\begin{gathered}
R(2019)=\frac{1596000}{1318320} \times 100 \%=121 \% \\
R(2020)=\frac{1642000}{2780820} \times 100 \%=59 \% \\
R \text { (forecast 2021) }=\frac{2010200}{5210115} \times 100 \%=38 \%
\end{gathered}
$$

The calculations of the profitability of a small confectionery enterprise reflect that the implemented strategy for the development of this small confectionery enterprise is ineffective and requires processing. According to the calculations, we note a decrease in the level of operational efficiency due to an increase in the aver age value of long-term loans and borrowings by 2021 .

\section{Conclusions}

The specified indicators of the profitability of the enterprise reflect the degree of profitability of its funds and are important relative indicators. Thus, the proposed system 
of performance indicators makes it possible to correctly assess the state, measure its quality level, identify significant deficiencies in the organization of management and used reserves, and outline ways of improvement.

\section{References}

1. Y. Mu-Jeung, L. Nicholas, L. Kueng, The impact of emerging $m$ arket compet ition on innovation and business strategy: Evidence from Canada, Journal of Economic Behav ior \& Orga nization 181, 117-134 (2021) doi.org/10.1016/j.jebo.2020.10.026

2. M. Queiroz, P. P.Tallon, T. Coltman, R. Sharma, P. Rey nolds, Aligning the IT port folio with bus iness strategy: Ev idence for co mplementar ity of corpo rate and bus iness unit a lignment, The Journal of Strateg ic Informat ion Systems 29(3), 101623 (2020) doi.org/10.1016/j.jsis.2020.101623

3. Y.-E. Lin, Y.-W. Li, T. Y. Cheng, K. Lam, Corporate social respons ibility and investment efficiency: Does bus iness strategy matter? 73, 101585 (2021) doi.org/10.1016/j.irfa.2020.101585

4. E. M.Olson, K. M.Olson, A. J. Czaplewski, T. M. Keya, Business strategy and the management of digital marketing, Business Horizons (2021) doi.org/10.1016/j.bushor.2020.12.004

5. R. Zi mmermann, L. Miguel, D.F. Ferreir, A. C. Moreira, How supply c hain strateg ies moderate the relationship betwee $\mathrm{n}$ innovation capabilit ies and bus iness perfo rmance, Journal of Purchasing and Supply Management 26, 100658 (2020) doi.org/10.1016/j.sbsp ro.2014.12.522

6. E. Soltani, Business and project strategy alig nment: ICT project success in Iran, Technology in Society 63, 101404 (2020) doi.org/10.1016/j.techsoc.2020.101404

7. H. Shakerian, H. D. Dehnavi, S. B. Ghanad, The Impleme ntation of the Hybrid Mode 1 SWOT-TOP SIS by Fuz zy Approach to Evalu ate and Ra nk the Hum an Resources a nd Business Strategies in Organizations (Case Study: Road and Urban Deve lopment Organization in Yazd), Procedia - Soc ial and Behavioral Sc iences 109, 1130-1141 (2014) doi.org/10.1016/j.sbsp ro.2016.09.039

8. L. Zuo, C. Wang, Q. Sun, Sustaining WEEE collect ion business in China: The case of o nline to o ffline (O2O) deve lopment strategies, Waste Manage ment 230, 307-316 (2016) doi.org/10.1016/j.wasman.2019.10.008

9. K. Tamaki, M. Arakaw, M. Aramec, Y. Ono, Development of Educatio nal Progra ms for Syste $m$ Creators and Business Producers in Future Strategy Des ign in Act ion Project Group Activities Through Industry-University Coope ration, Procedia Manufactu ring 39, 1377-1382 (2019) doi.org/10.1016/j.promfg.2020.01.319

10. J. Fr aser, Creating s hared value as a bus iness strategy for mining to adv ance the U nited Nations Sustain able Develop ment Goals, The Extract ive Indust ries and Soc iety 6(3), 788-791 (2019) doi.org/10.1016/j.exis.2019.05.011

11. I.-M. García-Sánchez, B. Aibar-Guzmán, C. Aibar-Guzmán, L. Rodríguez-Arizac, "Sell" reco mmendations by a nalysts in respo nse to bus iness commu nication st rategies concerning the Sustain able Develop ment Goals and the SDG co mpass 255, 120194 (2020) doi.org/10.1016/j.jclepro.2020.120194

12. H. Cha, A paradigm s hift in the g lobal strategy of MNEs tow ards business ecosyste ms: A rese arch agend a for new theory deve lopment, Journal of I nternation al Manageme nt 26, 100755 (2020) doi.org/10.1016/j.intman.2020.100755 
13. K.A. Barmuta, A.A. Borisova, M.P. Glyzina, Features of the mode rn system of management of deve lopment of e nterprises. Med iterranean Jou rnal of Soc ial Sciences 6(3S4), 91- 96 (2015) doi: 10.5901/ mjss.2015.v6n3s4p91

14. V.V. Mazur, K.A. Barmuta, S.S. Demin, E.A. Tikhomirov, M.A. Bykovskiy, Innovation clusters: Advantages and disadvantag. International Journal of Economics and F inancial Issues, 6(1S), 270- 274 (2016)

15. K. Barmuta, V. Ponkratov, M. Maramygin, N. Kuznetsov, V Ivlev, M. Ivleva, Mathematic al model of optimizing the bal ance sheet st ructure of the Russian b anking syste $\mathrm{m}$ with allow ance for the foreign exchange ris $\mathrm{k}$ levels. Entrepreneu rship and Sust ainability Issues 7(1), 484-4 97 (2019) doi: 10.9770/jes i.7.1(34)

16. N. S. Plaskova, N. A. Prodanova, A. S. Samusenko, E. A. Erzinkyan, K. A. Barmuta, R. A. Shichiyakh, Investment dec isions for mation: In novative assets. Internation al Journal of Engineer ing and Advanced Tech nology 9(1), 2913-2916 (2019) do i:10.35940/ijeat.A1213.109119 